\title{
ARTICLES
}

Submitted 07.11.2017. Approved 05.08.2018.

Evaluated by double blind review process.

DOI:http:///dx.doi/10.12660/joscmv11n2p75-89

\section{THE BRAZILIAN OCEAN FREIGHT OSCILLATION: THE EXPERTS' EXPLANATION TO THE USA, EUROPE AND CHINA TRADE}

\begin{abstract}
This study aimed to identify the variables that contribute to the oscillation of the international ocean freight of the Brazilian trade of containerized cargoes. The ocean freight from and to East Coast of United States, Northern Europe and China to Brazil was studied by a qualitative approach through in-depth interviews with a panel of seven experts in charge of pricing the international ocean freight in the largest international shipping companies operating in Brazil. After a first round with the experts, a table that tried to capture the causal relationship among variables and their influence in Brazilian ocean freight was developed. In a second round of interviews, the final table was submitted to the judgment of the experts. Considering the experts' opinion on the trade routes studied, it was noticed that the relationship between supply and demand with ocean freight is the variable that influences freight rates in Brazil's trade the most. Other variables such as vessels capacity, operating costs and competitors are among the variables that experts have identified as those that most contribute in Brazilian ocean freight oscillation.
\end{abstract}

KEYWORDS | Ocean freight, Brazilian maritime freight, containerized cargoes, Brazilian international trade, international logistics.

\section{Felipe Búrigo Balthazar}

felipe.balthazar@expeditors.com

Marcelo André Machado

mmachado@unisinos.br

Guilherme Luís Roehe Vaccaro

guilhermev@unisinos.br

Universidade do Vale do Rio dos Sinos, São Leopoldo, RS, Brazil 


\section{INTRODUCTION}

Many companies have realized the importance of trading products, raw materials, or even services at lower costs, higher quality, and wider variety. In this sense, the question is not about whether to look for more international resources or not, but how to manage this process and make it more efficient (Aykol, Palihawadana, \& Leonidou, 2013; Grama, 2014; Trent \& Monczka, 2003). Therefore, exporters and importers are more attentive to the costs involved in these processes, in order to make their products more competitive and, by logistic management, to establish policies that enable them to reduce costs and improve service level to the customer (Bygballe, Bø, \& Grønland, 2012).

Transport costs represent a critical component of importation and exportation prices, and influence the development of a supplier or a customer (Anderson \& Van Wincoop, 2004; Monroe et al., 2014). Freight rates bear a larger importance, compared to tax barriers (Binkley \& Harrer, 1981; Hummels, 2001; Jacks \& Pendakur, 2010). According to Fleury, Wanke, and Figueiredo (2012), generally production and marketing costs represent more than $70 \%$ of a company's revenues, while logistics costs stand at $19 \%$. In addition, Ballou (2004) declares that $60 \%$ of logistic expenses originate in transportation, which explains the importance of managing freight rates, whether in domestic or international routes. These percent values prove that logistic expenses play a considerable part in the composition of the total cost of a product, which is why such values are the object of consistent reduction efforts as a means to improve profit margins.

On the other hand, in 2015, dry cargo shipments accounted for about $71 \%$ of total seaborne trade volumes, which means that "maritime transport is the backbone of globalization and lies at the heart of cross-border transport networks that support supply chains and enable international trade" (UNCTAD, 2016).

According to the Brazilian Ministry of Development, Industry, and Foreign Trade (MDIC, 2017), by the end of 2015, 90\% of Brazil's international trade was transported by sea. Ocean freights placed on these imports and exports are formed by several variables. Although several studies have investigated some of these variables, such as the kind of goods shipped (Ho, Chiu, Chung, \& Lee, 2017; Ortúzar \& Willumsen, 1994), supply and demand (Jacks \& Pendakur,
2010; Notteboom \& Rodrigue, 2008; Ortúzar \& Willumsen, 1994; Stopford, 2009), distance covered by the vessel (Banomyong, 2005; Hesse \& Rodrigue 2004; Malchow \& Kanafani, 2004), and vessel capacity (Leach, 2014; Notteboom \& Rodrigue, 2008; Stopford, 1997), there are not many studies that addressed the variables behind the oscillations in international ocean freight rates set for exports and imports in the main routes serving emerging markets as Brazil.

The Brazilian Ministry of Development, Industry, and Foreign Trade (MDIC, 2017) indicates that the main economic regions that import to or export from Brazil are North America, Europe, and China. For Mongelluzzo (2013), the world's largest ports on a container flow basis are located in these continents. In the top 50 list, North America is represented by the Los Angeles, Long Beach, and New York ports with 8.08 million, 6.05 million, and 5.53 million of twenty-foot equivalent units (TEUs), respectively. In Europe, the largest ports are in the north, and include the ports of Rotterdam, Hamburg, and Antwerp with 11.87, 8.86, and 8.64 million TEUs, in that order. The Shanghai, Singapore, and Hong Kong ports are the main ones in Asia with 32.53, 31.65 , and 32.13 million TEUs. In the same list, Brazil is represented by the port of Santos, which runs around 3.17 million TEUs. For this reason, Santos was chosen as a destination port, while Shanghai, Rotterdam, and New York (since it is located on the east cost of the USA) were selected as main ports in the analysis of freight volumes in the present study.

In this scenario, this study identified the variables that influence on the oscillations in international ocean freight rates for Brazilian containerized trade with its major markets. The investigation considered the perspective of the three largest cargo trade volumes with Brazil: the USA East Coast, Northern Europe, and China. The views and notions of a panel of experts active in three main company classes were analyzed: shipowners, co-loaders, and freight forwarders. The inclusion of these experts in different sectors helped understand the perceptions held by organizations that, despite sharing the same objective in terms of cargo transportation, could see the pricing of ocean freight rates from different points of view.

This article presents, first, a review of the theoretical background on the subject and the contribution of the variables that influence on the oscillations in 
international ocean freight rates. Secondly, it will be discussed the methodological aspects to collect and analyze the data. After that, the data analysis obtained for the freight levels and the variables that influence the most on the oscillations observed are presented, as well tries to offer a proposal of a causal relationship among variables that influence freight in the trades studied. Finally, the implications of these variables are discussed.

\section{THEORETICAL BACKGROUND}

\section{The supply chain and logistics}

The globalization process has left a trail of economic uncertainties (Jacks \& Pendakur, 2010). The increasing exchange of goods and services across nations has substantially acerbated interdependence and economic volatility. Local changes and crises bear immediate consequences and tend to spread globally.

Revisions in dollar exchange systems, recession, new international trade regulations, and higher oil prices are some of the uncertainty factors that affect a globalized economy on a daily basis. For logistics, which has to act based on a prediction of demand, producing and placing the correct product in the right place at the right time and at a fair price, increased economic uncertainties elicit significant difficulties to predict sales and plan activities (Fleury et al., 2012; Hesse \& Rodrigue, 2004).

The supply chain, according to Bowersox, Cooper, Closs, and Bowersox (2014), encompasses companies that cooperate in order to leverage a strategic position and to improve operational efficiency. Ballou (2004) summarizes logistics and the supply chain as a "set of functional activities (transportation, inventory control, etc.) that repeat numerous times along the channel through which raw materials are converted into finished products, to which value is added in the eyes of the customer" (p. 29).

Since logistics is part of the supply chain, Bowersox et al. (2014) define it as the effort required to transfer and place an inventory in the supply chain. Banomyong (2005) agrees, adding that logistic management is an integrative process that aims to optimize the flow of materials and inputs provided by suppliers in the whole organization in order to meet customer's expectations. It is by a logistic process that materials travel inside the production capacity in an industrialized country, that products are distributed to consumers, and that value is generated to custom- ers, suppliers, and any other stakeholder (Bygballe et al., 2012; Monroe, Teets, \& Martin, 2014).

\section{The international ocean shipping system}

The role played by transportation in a logistics system is more complex than that of the transport of goods to customers (Zeng \& Rosetti, 2003). This complexity may take effect only through a highly qualified management team. A well-managed system affords to transport goods to the right place, at the right time, aiming to meet the customers' need. It is transportation that helps promote efficacy, establishing a link between producers and consumers (Daividsson, Henesey, Ramstedt, Törnquist, \& Wernstedt, 2005). Therefore, transportation is the basis of efficiency and savings in corporate logistics, and enhances other functions of the logistics system (Ballou, 2004; Grama, 2014). In addition, a good transportation system in a logistics network is beneficial not only to the quality of service, but also to a company's competition potential (Tseng, Yue, \& Taylor, 2005).

It is widely accepted that water is the oldest means of transport. Ancient sailboats were replaced by steamboats in the XVIII century, and by diesel-propelled vessels around 1920's (Bowersox et al., 2014). Ships were first used to transport containers in 1956, when Malcolm McClean shipped the first cargo trailers towed by a 60-TEU World War II tanker, sailing from Newark, New Jersey, to Houston, Texas. Until then, most cargoes were transported loosely on ships, placed in wooden structures whose aim was to enable to hoist and to move goods by cranes on ports and on ships (Stopford, 1997). The result was that cargo ships spent about two thirds of operational time on ports, and that handling costs reached approximately one fourth of the total expenses. With increasing cargo volumes, this mode of operation became unfeasible both operationally and economically (Binkley \& Harrer, 1981; Notteboom \& Rodrigue, 2008).

The main advantage of ocean transport lies in the possibility to ship extremely large cargoes, besides lower costs when compared to airfreight (Ballou, 2006; Bowersox et al., 2014). As drawbacks, Tseng et al. (2005) highlight the longer delivery times, apart from the need to schedule mooring operations depending on weather factors. Other negative aspects include the distance between ports and production centers, and the need to invest in robust packaging solutions in order to protect goods, especially 
against possible damage caused by mishandling during loading and unloading operations.

\section{Ocean shipping costs to containerized cargoes}

The advent of container transport in the 1960s changed irreversibly the environment of the global transportation business and it has become increasingly competitive due to the economic globalization (Finke \& Kotzab, 2017; Fung, Cheng, \& Qiu, 2003; Notteboom \& Rodrigue, 2008). At the same time, along with market uncertainty, freight tariffs have been one of the highest priorities for importers and exporters since 2000, because container shipping lines have provoked great bargaining over price (Ho et al., 2017). In this sense, shipping rates can be defined as the fees charged by transportation companies when providing services, that is, the payment to cover the costs of transportation between two locations and the expenses associated with the maintenance of a traveling inventory (Grama, 2014; Sahin, Yilmaz, Ust, Guneri, \& Gulsun, 2007).

The revenue of container shipping firms and, therefore, the freight price, is dependent on an interaction between price and quantity. That means the freight rate represents the price, and the quantity refers to the spaces used in a container vessel. So, the balance must be reached to offer a reasonable freight and, at same time, to transport cargoes that occupy the spaces in the vessel (Notteboom \& Rodrigue, 2008; Tang \& Sun, 2018).

In this sense, freight all kinds (FAK) is a general rate defined by shipowners to classify any goods being transported. As a rule, FAK is higher than the values charged to ship goods at loading, exactly to cover for all cargo types, including dry cargoes (Bowersox et al., 2014; Maloni, Paul, \& Gligor, 2003). Dry cargo is the term used to describe materials that do not need special care during loading. As opposed to gaseous or liquid loads, dry cargoes may be shipped in containers with no special temperature control measures. Dry cargoes are several types of cargo, such as dry finished products, metals (such as iron and steel), and even some heat and cold-tolerant grains (Ballou, 2004; Bowersox et al., 2014; Ho et al., 2007).

On the other hand, there are many costs that affect container freight that are not linked to the cost of shipping the goods. One of the most common is the terminal handling charges (THC) that are fees charged by shipping lines to cover costs of moving containers from the terminals to the ships (Fung et al., 2003; Slack \& Gouvernal, 2011) Another important cost for containers is regarding the storage of empty containers in the terminal or in another warehouse abroad, while awaiting its reuse, as well as the costs of management and organization of the container reposition (Finke \& Kotzab, 2017; Steenken, Voß, \& Stahlbock, 2004).

Nevertheless, in pricing ocean freight rates, it was observed that several factors must be considered and some of these variables were discussed in several studies published in the past 20 years. So we have tried to summarize the main constructs that, at some point, interact with freight rates and have the power to provoke an oscillation of its level. A review of those studies enabled the identification of 12 variables to be analyzed by the panel of experts, with the purpose of understanding the contribution of these aspects to the oscillations in freight rates, according to Exhibition 1.

Exhibition 1. Variables that influence ocean freight rates

\begin{tabular}{|c|c|c|}
\hline Product/ Commodity & $\begin{array}{l}\text { Several factors, based on density, packaging, facility to } \\
\text { handle, and risks affect the freight rate of a product. }\end{array}$ & $\begin{array}{c}\text { Ballou (2004), Bowersox et al. (2014), } \\
\text { Fung et al. (2003), Ortúzar and } \\
\text { Willumsen (1994) }\end{array}$ \\
\hline $\begin{array}{l}\text { Cargo weight and } \\
\text { volume }\end{array}$ & $\begin{array}{l}\text { The heavier the container, the higher the shipping } \\
\text { costs. In addition, shipowners have to identify the best } \\
\text { location of a container on board to balance it with other } \\
\text { containers on the deck. Light cargoes are preferred, since } \\
\text { they consume less fuel and cause less concern to the total } \\
\text { weight of the ship. }\end{array}$ & $\begin{array}{l}\text { Ballou (2004), Bowersox et al. (2014), } \\
\text { Notteboom \& Rodrigue (2008), } \\
\text { Steenken et al. (2004), Tang and Sun } \\
\text { (2018) }\end{array}$ \\
\hline
\end{tabular}

(continue) 
(conclusion)

\begin{tabular}{|c|c|c|}
\hline Supply and demand & $\begin{array}{l}\text { Demand influences directly the freight rates, since it } \\
\text { involves the market supply and demand relationships. In } \\
\text { other words, when supply is high and demand is low, rates } \\
\text { tend to go down, and vice-versa. }\end{array}$ & $\begin{array}{l}\text { Ballou (2004), Ortúzar and } \\
\text { Willumsen (1994), Sahin et al. (2007), } \\
\text { Stopford (2009), Zeng and Rossetti } \\
\text { (2003) }\end{array}$ \\
\hline Distance sailed & $\begin{array}{c}\text { A large number of the studies reviewed cover the } \\
\text { composition of freight rate considering distance as the } \\
\text { main factor in the definition of rates, independently on } \\
\text { transport mode. }\end{array}$ & $\begin{array}{l}\text { Banomyong (2005), Bowersox et al. } \\
\text { (2014), Ho et al. (2017), Maloni et } \\
\text { al. (2013), Malchow and Kanafani } \\
\text { (2004), Hesse and Rodrigue (2004) }\end{array}$ \\
\hline $\begin{array}{l}\text { Cargo size/number } \\
\text { of containers }\end{array}$ & $\begin{array}{l}\text { When shipowners price a loading operation of one single } \\
\text { container, the rates charged are normally excluded } \\
\text { from the general FAK classification of product and rates. } \\
\text { However, when cargo size and number of containers are } \\
\text { known, a differentiated pricing strategy is adopted, if the } \\
\text { other variables with the goods transported allow reducing } \\
\text { ocean freight rates. }\end{array}$ & $\begin{array}{l}\text { Florentino (2010), Notteboom and } \\
\text { Rodrigue (2008), Slack \& Gouvernal } \\
\text { (2011), Zeng and Rossetti (2003) }\end{array}$ \\
\hline Operational costs & $\begin{array}{l}\text { Operational costs may affect the freight rate in different } \\
\text { routes distinctively, since regional differences, such as the } \\
\text { interaction between demand and supply of the shipped } \\
\text { service, may inhibit the rise in freight rates. }\end{array}$ & $\begin{array}{l}\text { Finke and Kotzab (2017), Fung et } \\
\text { al.(2003), Grama (2014), Malchow } \\
\text { and Kanafani (2004), Notteboom } \\
\text { and Rodrigue (2008), Sahin et al. } \\
\text { (2007), Stopford (2009) }\end{array}$ \\
\hline Route & $\begin{array}{l}\text { Freight may vary with departure and destination sites, and } \\
\text { with the route followed. }\end{array}$ & $\begin{array}{l}\text { Malchow and Kanafani (2004), } \\
\text { Ballou (2004), Banomyong (2005), } \\
\text { Bowersox et al. (2014), Hesse and } \\
\text { Rodrigue (2004), }\end{array}$ \\
\hline $\begin{array}{l}\text { Economic situation } \\
\text { of countries }\end{array}$ & $\begin{array}{l}\text { Higher rates are charged in emerging economies, } \\
\text { compared to developed countries, resulting in lower } \\
\text { business volumes and revenues. }\end{array}$ & $\begin{array}{l}\text { Hummels, Lugovskyy and Skiba } \\
\text { (2008), Jacks and Pendakur (2010), } \\
\text { Lee and Lee (2012), Murray (1996) }\end{array}$ \\
\hline $\begin{array}{l}\text { Possibility to return } \\
\text { cargoes }\end{array}$ & $\begin{array}{l}\text { The freight involves not only shipping costs, but also the } \\
\text { shipping options available in the departure site and the } \\
\text { possibility to return the cargo to the departure point. }\end{array}$ & $\begin{array}{l}\text { Finke and Kotzab (2017), Grama } \\
\text { (2014), Notteboom and Rodrigue } \\
\text { (2008) }\end{array}$ \\
\hline $\begin{array}{l}\text { Bunker Adjustment } \\
\text { Factor (BAF), } \\
\text { additional fee for } \\
\text { fuel. }\end{array}$ & $\begin{array}{l}\text { Shipowners see fuel consumption as one of the main } \\
\text { factors, since lasting oscillation in crude oil prices interferes } \\
\text { directly in shipping. }\end{array}$ & $\begin{array}{l}\text { Maloni et al. (2013), Notteboom } \\
\text { and Cariou (2013), Notteboom and } \\
\text { Rodrigue (2008) }\end{array}$ \\
\hline Competition & $\begin{array}{l}\text { Shipowners that do not face competition in determined } \\
\text { route charge higher freight rates. }\end{array}$ & $\begin{array}{l}\text { Ho et al. (2017), Hummels et al. } \\
\text { (2008), Notteboom and Rodrigue } \\
\text { (2008), Sahin et al. (2007) }\end{array}$ \\
\hline Vessel capacity & $\begin{array}{l}\text { Freight is affected by the relationship between ship } \\
\text { capacity and demand. }\end{array}$ & $\begin{array}{l}\text { Leach (2014), Notteboom and } \\
\text { Cariou (2013), Stopford (2009) }\end{array}$ \\
\hline
\end{tabular}

\section{RESEARCH DESIGN}

The variables that influence ocean freight rate oscillation in Brazilian trade to the USA, Europe and China were analyzed using a qualitative approach due to the need of a wide and in-depth perspective of the study problem and the nature of the issue (Creswell, 1998). A qualitative study also enables greater flexibility, since several aspects associated with the fact or with the phenomenon under investigation are considered.
The research design for this study was divided in four steps, according to Figure 1 . The first step started with the literature review, when, at the end, 12 variables responsible for oscillations in international freight rates were identified, according to Exhibition 1. Based on the 12 variables identified, a panel of experts was assembled, formed by managers responsible for pricing ocean freight rates in Brazil in their companies. The panel was arranged in order to obtain confirmation of the effect of the 12 variables on freight rates as well as to understand the relationships among those variables and between these and ocean freight. 
Figure 1. Methodological steps

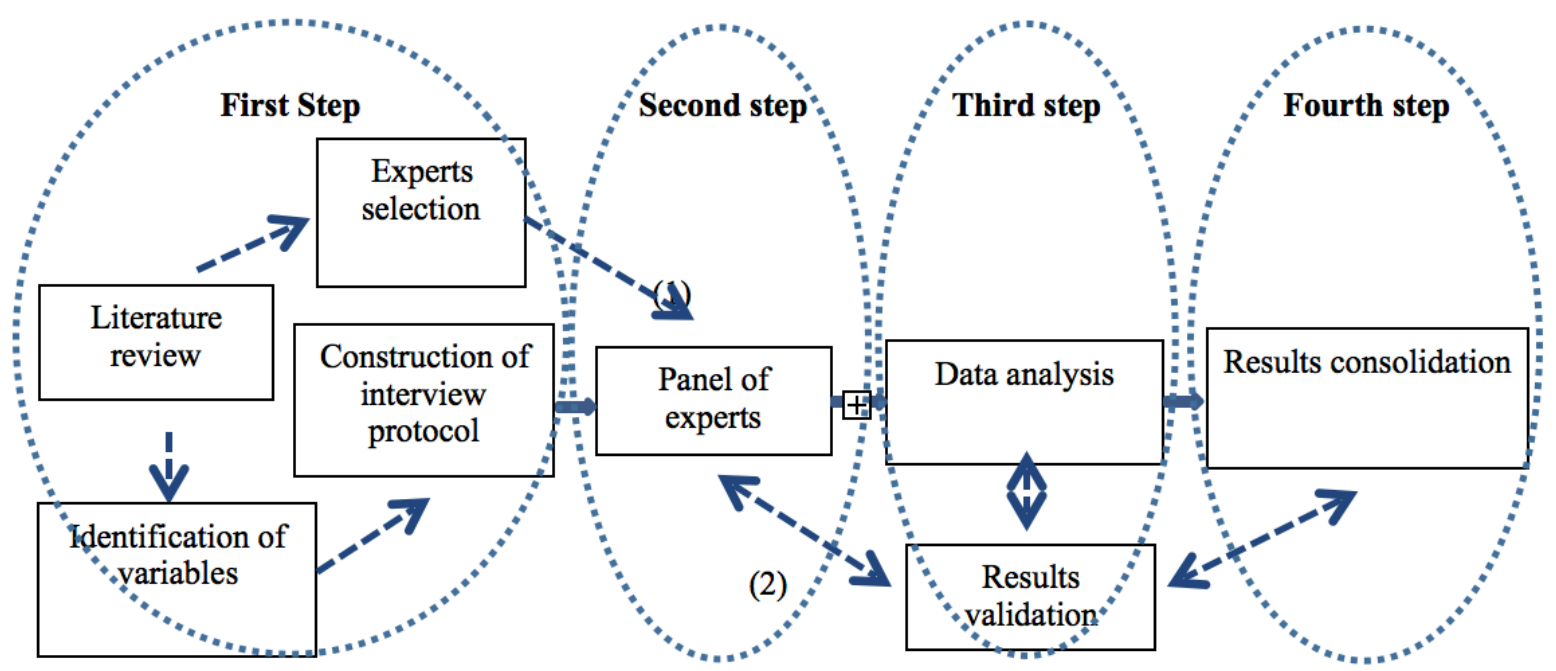

(1) First round of interviews.

(2) Second round of interviews.

Consulting other people's opinions has been commonly used as a strategy in the decisions involving themes surrounded with great responsibilities in terms of results or controversial subjects that entangle quite complex variables that lead to uncertainties as to the possible results (Yaniv, 2004). According to Budescu and Rantilla (2000), expert panels are recommended when (i) there is a need to make a decision in the short term, (ii) the possible results are surrounded with uncertainties, (iii) relevant information that may mitigate uncertainties is available, and (iv) it is possible to confer with experienced professionals who have relevant information.

To select the right specialists to perform an expert panel it is recommended a group of, at least, six judges with large experience on the subject to be discussed, according to Yaniv (2004). In this sense, the 13 most representative shipowners around the globe (Alphaliner Top 100, 2016), with operations in Brazil, were invited personally and by phone to become part of the panel. At the end of this phase, five shipowner representatives in Brazil agreed to participate in the panel.

In order to add different perspectives regarding freight rates, the researchers asked the five specialists to indicate freight forwarders and co-loaders that also offered maritime freight in Brazil. The five specialists indicated the same freight forwarder, classified as the 7th largest company in the seg- ment, according Armstrong \& Associates (2015), and one co-loader with consistent Brazilian market share. After a phone invitation, these two firms accepted to join de panel, as described in Exhibition 2.

In the second step, a first round of in-depth interviews with the seven experts was conducted. The third step consisted of the content analysis to assess the data as a means to understand the behavior of the variables pointed in Exhibition 1 and that influence ocean freight rates of containerized dry cargoes for Brazilian trade with the USA, Europe and China. For Bardin (1977), this analytical technique comprises three stages: (i) pre-analysis, (ii) exploitation of the material, and (iii) treatment and interpretation of results. Here, content analysis was chosen since, according to Kolbe and Burnet (1991), it is an observational research method that is used to systematically evaluate the symbolic content of all forms of recorded communications. To accomplish that, the analysis categories were restricted to the 12 variables identified previously in Exhibition 1.

After the content analysis of the first round of indepth interviews (Exhibitions 3 and 4), the authors developed a table with the behavior of twelve variables listed in the context of Brazilian ocean freight, in order to capture the relationship among them. So, in the fourth step the relationship table was presented again to the same panel in a second round 
of in-depth interviews with the aim of obtaining a consensus (Budescu \& Rantilla, 2000) regarding the association between variables and international ocean freight (Exhibition 5).

\section{DATA ANALYSIS}

In the first round of interviews with the panel of experts, the 12 variables identified in the literature review (Exhibition 1) were presented to the panel, who evaluated the importance of each in international ocean freight pricing. The panel ascribed a score to variables in a $0-5$ scale, in which 0 denotes the absence of any influence in pricing, while 5 indicates a strong effect on the definition of freight rates. Therefore, according to the panel, the variables supply and demand and vessel capacity, both with score 4.71 , had the strongest influence on freight pricing. On the other hand, the variables distance sailed by vessels and economic situation of countries involved in the importation/exportation business, both with 2.57 , were the ones with the lowest score, showing that they were the ones that least influence freight pricing.

After that, the experts were invited to talk about the variables that influence de freight oscillation and the possible explanations for those evidences. The Specialist E1 declared that "shipowners are increasingly looking for financial return in order to recover losses in previous years, though freight rates are consistently observed to fall in some trades".

To identify the cutoff value in the time series, four interviewees declared that a 3-year survey about trends in the markets involved in these trades would suffice. However, specialist E6 warned that:

When it comes to China imports, even a 10 -year time series of freight rates would not afford to understand the reasons behind such oscillations, let alone predict freight rates in the next five years. For Europe, two years are enough to see that the market is stable, which allows for more assertive predictions.

In this sense, the authors decided to separate the analysis into two sets of trades: Brazilian freight rates with the USA and Europe trade, which represents a trade with more stable freight rates; and Brazilian freight rates with China trade.

\section{Variables affecting freight in Brazilian, USA East Coast and Northern Europe trade}

The freight rates charged by four global shipowners (all of whom are European) for trade with the USA East Coast were analyzed by the experts considering the New York port, which is the busiest one in terms of twenty equivalent unit (TEU) container flow in the region. According to the specialists, these rates were considered relatively low and could pose a risk to the financial health of shipowners operating in this trade route (Jacks \& Pendakur, 2010).

The data analysis revealed that ocean freight rates in this trade also decreased in the recent years. According to the experts, this trade route exhibited a stabilization trend with minor pricing changes, though rates decreased consistently for a long period of time. The average freight of all kind (FAK) rate was about USD 1800 in 2012 and fell to USD1000 in 2014 , pointing to a decrease in annual mean values. According to the specialists, this scenario may induce players to cease to offer freight services to the USA east coast, due to the low demand and freight rates, which makes business less attractive to most shipowners.

On the other hand, the freight rates were evaluated for a northern Europe trade route considering the Brazilian port of Santos and the Rotterdam, Hamburg, and Antwerp ports. The same process was carried out for freights between these European ports and Brazil. Three European and one Asian shipowners were considered, all of whom provide freight services based on their own ships. The average FAK in this route has been falling on a yearly basis. The freight rates exhibited a trend towards stabilization, despite the rises and drops observed at times, according to the experts.

To understand the trend exhibited by shipowners towards maintaining international freight rates within a safety net in these two trade routes (northern Europe and USA east coast), the specialists were inquired over the variables that helped to maintain these rates essentially free of oscillations. The answers provided point to an interaction between these variables, which afforded to analyze them separately and then establish a link between them and the other answers. Exhibition 3 presents the variables that helped maintain the stability in freight rates, as listed by the participant experts. 
Exhibition 2. The panel of experts

\begin{tabular}{c|c|c|c|c|c}
\hline Expert interviewed & Firm Position & $\begin{array}{c}\text { Years in ocean } \\
\text { freight }\end{array}$ & Firm Type & $\begin{array}{c}\text { Firm's Country of } \\
\text { origin }\end{array}$ & $\begin{array}{c}\text { Year of } \\
\text { foundation }\end{array}$ \\
\hline E1 & Regional Manager & 14 & $\begin{array}{c}\text { Freight } \\
\text { Forwarder }\end{array}$ & USA & 1979 \\
\hline E2 & Pricing Manager & 8 & Shipowner & Germany & 1970 \\
\hline E3 & Pricing Manager & 18 & Co-loader & Brazil & 1994 \\
\hline E4 & $\begin{array}{c}\text { Global Account } \\
\text { Manager }\end{array}$ & 18 & Shipowner & Denmark & 1904 \\
\hline E5 & $\begin{array}{c}\text { Pricing Manager } \\
\text { Commercial } \\
\text { Manager }\end{array}$ & 17 & Shipowner & Canada & 1993 \\
\hline E7 & Traffic Manager & 6 & Shipowner & Chile & 1970 \\
\hline
\end{tabular}

Specialist E1 added:

No considerable change in demand and supply issues were recorded in these markets... the services provided by shipowners during the period did not change as in other trade routes, like the China trade route, for instance... in addition, I think that the kind of goods shipped in these markets reduces the variation in freight rates.

The answers obtained allowed for the identification of some relationships between variables, such as predicting the markets where no change in the services offered will take place induces shipowners to maintain freight rates. In a similar way, the capacity of vessels, when adjusted for the demand, has the same effect for a 1-year period. Moreover, since the countries where the ports considered enjoy a level of economic activity, it is presumed that freight rates will remain essentially constant and within a safety margin, similarly to the other figures.

\section{Variables affecting freight in Brazilian and China trade}

The FAK rates applied by six shipowners (three Asian, three European) offering their own services and vessels in the China trade route to Brazil were evaluated by the specialists for a period of five recent years. The results indicated that FAK rates remained constant for more than 30 days, when importation from China is analyzed. Freight rate in this route in 2012 was USD1822 by TEU, and fell to USD1229 in 2013 and to USD1070 in 2014.

The content analysis of the questions addressed to the panel of experts showed that several variables influence freight rates for China trade with Brazil, according to Exhibition 4. The variable about the supply capacity and the market demand for international ocean transportation was mentioned by all specialists, though other variables were also mentioned as playing a role in the variations observed.

Exhibition 3. Variables influencing freight rates in Brazil, Europe and the USA trade

\begin{tabular}{|c|c|c|}
\hline \multirow{7}{*}{ 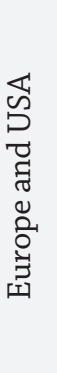 } & E1 & Supply and demand; Commodity; operational costs. \\
\hline & E2 & Vessel capacity; Cargo weight and volume; Competition. \\
\hline & E3 & Supply and demand; Vessel capacity; Competition. \\
\hline & E4 & Supply and demand; Vessel capacity; Competition. \\
\hline & E5 & Supply and demand; Vessel capacity. \\
\hline & E6 & Supply and demand; Vessel capacity; Return cargo. \\
\hline & E7 & Economic situation; Commodity; Supply and demand. \\
\hline
\end{tabular}


The analysis also revealed that the variables listed by specialists as responsible for the persistent oscillations in containerized dry cargo ocean freight rates in the China trade route are exactly the same as those that explain the relatively constant values on a yearly basis in the east USA coast and northern Europe routes, as shown in the previous section. In addition, it should be highlighted that the specialists pointed out the trend in large shipowners to form new partnerships. This would eventually add to the stability in the ocean freight rates, since they would become more profitable for freight companies, which could charge higher rates as compared to those reported in the present study.

\section{Proposal of a causal relationship among individual variables}

One of the objectives of this study was to understand the dynamics among the variables that influence ocean freight rate of Brazilian trade with the USA,
Europe and China. Therefore, the set of data offered by the specialists in the first round of in-depth interviews were combined with the objective of proposing a set of causal relations for future quantitative analysis to validate its effects. However, some studies already explain the behavior of many variables in terms of ocean freight rates, which helped to a better understanding. (Ballou, 2004; Bowersox et al., 2014; Grama, 2014; Ortúzar \& Willumsen, 1994; Stopford, 1997; Florentino, 2010).

Therefore, Exhibition 5 shows the proposal of a causal relationship among individual variables related to Brazilian freight rates of trade to the USA, Europe and China and how theses variables affect ocean freight rates. As observed, the variables commodity, cargo weight, and number of containers were classified as direct variables in the context of ocean freight rates, since any increase or decrease in the values representing these variables elicit oscillations in ocean freight rates, according to the specialists.

Exhibition 4. Variables influencing freight rates in Brazil and China trade

\begin{tabular}{|c|c|c|}
\hline \multirow{7}{*}{ } & E1 & Operational Costs; Supply and demand; Vessel capacity. \\
\hline & E2 & Supply and demand; Vessel capacity. \\
\hline & E3 & Economic situation; Supply and demand. \\
\hline & E4 & Supply and demand; Vessel capacity; Economic situation. \\
\hline & E5 & Supply and demand; Vessel capacity. \\
\hline & E6 & Competition; Vessel capacity; Supply and demand. \\
\hline & E7 & No opinion. \\
\hline
\end{tabular}

Exhibition 5. Proposal of a causal relationship in Brazilian freight based on experts' opinion

\begin{tabular}{|c|c|c|}
\hline Variables & Relations among variables & Proposal of causal relations \\
\hline Commodity (Com) & $\begin{array}{l}\text { The higher the commodity value, the higher the } \\
\text { freight value }\end{array}$ & $+\mathrm{Com} \rightarrow+\mathrm{OFrg}$ \\
\hline Cargo Weight (CgW) & The heavier the container, the higher the freight. & $+\mathrm{CgW} \rightarrow+\mathrm{OFrg}$ \\
\hline $\begin{array}{l}\text { Number of Containers } \\
\text { (NoC) }\end{array}$ & $\begin{array}{l}\text { The higher the number of containers shipped, } \\
\text { the lower the freight by container. }\end{array}$ & $+\mathrm{NoC} \rightarrow(-) \mathrm{OFrg}$ \\
\hline Ocean Freight (OFrg) & $\begin{array}{l}\text { The lower the ocean freight, the higher the } \\
\text { demand. }\end{array}$ & \multirow{4}{*}{$\begin{array}{c}(-) \text { OFrg } \rightarrow+\text { Dem } \rightarrow+\text { Sup } \rightarrow \\
\rightarrow+\text { Comp } \rightarrow(-) \text { OFrg }\end{array}$} \\
\hline Demand (Dem) & $\begin{array}{l}\text { The higher the demand for ocean freight, the } \\
\text { higher the supply of ocean freight. }\end{array}$ & \\
\hline Supply (Sup) & $\begin{array}{l}\text { The higher the supply, the higher the competi- } \\
\text { tion. }\end{array}$ & \\
\hline Competition (Comp) & $\begin{array}{l}\text { The higher the competition, the lower the freight } \\
\text { value. }\end{array}$ & \\
\hline
\end{tabular}




\begin{tabular}{|c|c|c|}
\hline Supply (Sup) & $\begin{array}{l}\text { The higher the supply, the higher the capacity of } \\
\text { the vessel. }\end{array}$ & \multirow{4}{*}{$\begin{array}{c}+\mathrm{Sup} \rightarrow+\mathrm{CoV} \rightarrow+\mathrm{Fl} \rightarrow+\mathrm{OpC} \rightarrow \\
\rightarrow+\mathrm{OFrg}\end{array}$} \\
\hline $\begin{array}{l}\text { Capacity of the Vessel } \\
\text { (CoV) }\end{array}$ & $\begin{array}{l}\text { The higher the capacity of the vessel, the higher } \\
\text { the fuel consumption. }\end{array}$ & \\
\hline Fuel (FI) & $\begin{array}{l}\text { The higher the fuel consumption, the higher the } \\
\text { operating costs. }\end{array}$ & \\
\hline $\begin{array}{l}\text { Operational Costs } \\
\text { (OpC) }\end{array}$ & $\begin{array}{l}\text { The higher the operational costs, the higher the } \\
\text { freight value. }\end{array}$ & \\
\hline $\begin{array}{l}\text { Economic Situation } \\
\text { (EcSit) }\end{array}$ & $\begin{array}{l}\text { The lower the business volume, the lower the } \\
\text { possibility of return cargo. }\end{array}$ & \multirow{2}{*}{$(-)$ EcSit $\rightarrow(-) \operatorname{RetCg} \rightarrow+$ Frg } \\
\hline Return Cargo (RetCg) & $\begin{array}{l}\text { The lower the return cargo, the higher the freight } \\
\text { value. }\end{array}$ & \\
\hline
\end{tabular}

To endorse the relationships presented in Exhibition 5 , a second round of in-depth interviews was carried out to validate and to obtain a consensus in the panel of experts regarding the relationships observed among the variables listed.

Considering the variable commodity, five of the seven specialists agreed that the higher the value of the goods, the higher the freight charged will be. However, specialist 4 warns that "yes, it is considered so, but it is not the most important, since, for example, the rate charged for wood is the lowest in the market, compared with auto parts or medical drugs, which are higher".

Specialist 2 confirms this notion, though in a more objective way, saying that "a more expensive product costs more and, therefore, freight should also be charged at higher rates". Thus, in spite of the fact that most specialists agree on the relationship between commodity and ocean freight rate, some studies did not take it into consideration when pricing ocean freights (Bowersox et al. 2014; Ortúzar \& Willumsen, 1994). On the other hand, other studies pointed at the same direction as the specialists, stating that the cargo value impacts on freight rate due the risk of damage (Grama, 2014; Zeng \& Rossetti, 2003).

The variable weight/volume is directly related with ocean freight rate, since, according to the specialists, the greater the weight, the higher the rate. Six of the seven specialists agree on the relationship between cargo weight and ocean freight rate, consistent with Maloni et al. (2013), Bowersox et al. (2014), and Notteboom and Rodrigue (2008). For example, specialist 1 declares that "as a rule, this practice is used in the market. However, overweight surcharge is applied for loads in excess of 20 tons, and lighter cargoes admit better negotiation bargains".
Similarly, specialist 3 believes that "ocean freight companies usually define a maximum weight acceptable for transportation, considering the freight rate informed. When the container's weight exceeds this value, an additional fare is charged as overweight. It is a means to charge more for heavy equipment". Specialist 7 states that "cargo weight, many times, influences freight rate, since the heavier the cargo, the more difficult to fill TEU slots in the vessel".

The variable number of containers is interpreted in terms of the cargo volume to be shipped, since specialists declare that the larger the number of containers regularly shipped, the lower the ocean freight rate charged. This point was consistent with de findings of Maloni et al. (2013) and Notteboom and Rodrigue (2008). The seven specialists agreed that this variable is directly correlated with rates. As specialist 7 puts it:

When the customer has a larger cargo to ship, we may negotiate a lower rate. We are always interested in filling up the slots in vessels. Larger cargoes allow to fill slots more easily than one or two containers per client only.

Specialist 3 adds that:

This happens for some contracts only. It is always possible to obtain better rates when the volume being negotiated is large. Yet, when the demand for transportation in a route is too high, the trend observed is usually the other way round, due to the limitation in shipping capacity of vessels. Full vessels imply higher rates.

During the second round of results validation, based on the answers given by the specialists in first round of interviews (Exhibitions 3 and 4), some different statements were produced. The last 
round showed that the lower the ocean freight, the higher the demand for international transportation services. Therefore, shipowners attempt to increase the available space in vessels and, as a result, new players make extra efforts to enter this market. As a result, with increasing competition, the trend would be towards lower rates (Tang \& Sun, 2018).

The specialists reached a consensus on these relationships, though they brought a better explanation on the relationships that actually influence Brazilian ocean freight rates. Specialist 3 agrees on the relationship between these two variables, but adds that:

The entry of new competitors in a promising ocean route induces a drop or the stabilization of rates. However, the cargo should be such as to afford to appropriately fill the slots in vessels, since shipowners tend to reduce the supply of space in order to avoid losses when this supply is high and the volume to be shipped is not high enough. It should be remembered that low freight rates are not the main factor to attract more business or demand for ocean transportation (E3).

Specialist 7 agrees with the declaration above, and offered a more in-depth analysis of these variables:

The lower the ocean freight rate, the more companies feel encouraged to export, increasing demand, since transportation costs strongly influence the end cost of any operation in international trade. In a scenario of low rates, the main players will compete for cargoes, which will eliminate market space. As a result, freight rates rise again. Under low rates, there will always be players that can't follow the trend, which increases space. When rates are too low, new players may enter the market, as long as they manage to offer good service at the same freight rates as charged by the main competitors. Many times, smaller players can't proceed, due to the operational costs of the services they offer. But when they manage to, competition increases, which may promote a drop in freight rates, since there will be more options (E7).

However, specialist 6 disagreed with some relationships, and explained the reasons:

Demand for international transportation services should not be subject to oscillations due to high or low freight rates. There are other reasons, of socioeconomic character, at a given time. Freight varies, as a rule, due to the unused capacity in vessels.
This implies considering the entry of new players in trade routes (E6).

Specialist 4 agrees with specialist 6 , and adds:

If a specific service or route operates under low freight rates, shipowners do not underscore the supply of shipping space or even vessels, but the capacity is adjusted to the actual demand. Therefore, new players will hardly be able to enter this market, unless it is profitable (E6).

In this sense, some specialists argued that the low ocean freight rate boosts the demand for ocean transportation services, since it is directly correlated with competitiveness of exporter companies in the destination market (Notteboom \& Rodrigue, 2008). Nevertheless, other specialists believe that the demand for ocean transportation services is not affected by freight rates. Therefore, the opposing views were analyzed in terms of the variables supply and demand, which, according to the specialists, is the main relationship to influence international ocean freight rates.

As for competition, all specialists mentioned the constant efforts of shipowners to adapt the available space in vessels to the actual demand. Yet, new players are more inclined to start operations in trade routes where freight rates are not too low, or when a route shows good business opportunities. Shipowners are not interested in entering markets where slot availability exceeds the demand. In spite of that, the specialists agree that increased competition may lead to a decrease in ocean freight rates, consistent with the findings of Grama (2014), Maloni et al. (2013), and Hesse and Rodrigue (2004).

The second round of the variables validation showed the lower the ocean freight rate, the higher the demand for associated services. In this sense, shipowners would be inclined to increase the space available in vessels. If one takes into consideration that supply and demand would trigger the flow of goods, the commercial status of countries with a role in exportation and importation markets would reach a level of stability, which would reduce the need for replacing containers in the country of origin and, for this reason, the trend would be towards increasing ocean freight rates.

The specialists analyzed the relationships between ocean freight rate, demand, supply, economic situation, and return cargoes in order to produce a clear picture of the contribution of each in the oscillation of 
ocean freight rates. One specialist clarified the issue very objectively:

With increased demands, the flow of goods tends to rise. This may reduce the need for repositioning containers, both in the origin and in the destination countries. This alone does not lead to higher freight rates, though it may raise profit contribution each shipment generates to the carrier. It may be necessary to increase rates when there is a lack of equipment in the departure port and an excess of equipment in the destination port (E4).

Nevertheless, the specialists disagree on the relationships in which the increase in the demand for international transportation services and the increased supply of vessels directly contribute to the improvement in the commercial relationship between the countries involved in the operation. On the other hand, a consensus was reached on the fact that the improvement in commercial situation of countries increases the chances for containers not to be repositioned in the destination, which means a greater advantage to the shipowner, since it will not be necessary to charge a low freight rate (Fung et al, 2003).

In the analysis of the relationships involving the variables ocean freight rate, demand, supply, vessel capacity, fuel, and operational costs, the specialists explained their views about the pricing of ocean freight rates. Exhibition 5 shows that the lower the freight the higher the demand for international transportation services. So, shipowners would try to increase available space in the long run based on vessel capacity. Therefore, the costs associated with fuel in larger ships would also be expected to rise, increasing the operational costs of vessels. As a result, the final freight rate would be down against the unit cost to ship one container.

Specialist 7 agrees, and warns:

Larger vessels imply higher operational costs, though once they can carry larger numbers of units, this cost spreads across this extra volume. The freight rate is not necessarily reduced due to operational costs. However, large vessels require greater cargoes in order to fill up all slots. This need for more cargo is the factor that makes rates drop (E7).

Although large ships are designed to consume less fuel and therefore be more advantageous economically, they require greater effectiveness in the allocation of slots by shipowners (Fung et al., 2003;
Maloni et al., 2013). Therefore, by increasing capacity, shipowners need greater cargoes in order to load a ship to the full and split the high fuel and operational costs across the thousands of units on board.

According to the specialists interviewed, the trend for the years ahead is towards a readjustment in vessel capacity in trade routes in which ship occupation rates are below $70 \%$, depending on the time of year, as observed in the trade routes with China. Concerning market stability and freight rates, specialist 6 does not envisage a real market stability, not until 2018, exactly due to the increase in ship size and in slot availability. In addition, for specialist 6 , the balance between market demand and supplied capacity would be reached if shipowners stopped ordering new ships. However, orders for new ships and requests for increasingly larger ships are quite common today. This is disadvantageous to Brazil, since the port infrastructure is not fit to receive large ships, due to the large load-draught of these vessels and the logistic problems in the port and adjacent area.

At the same time, Brazil presents a delicate freight situation regarding its small share in worldwide trade. According to MDIC (2017), Brazil counts for about 1\% of the total of international trade and any exchange rate fluctuation increases or decreases the imports or exports, but not in the same way. So, as the transportation costs of an empty container are similar to the costs of a loaded one (Finke \& Kotzab, 2017), when Brazilian imports decrease, replacing the empty containers for Brazil results in additional costs and impacts on freight oscillation (Lee \& Lee, 2012).

\section{IMPLICATIONS AND FINAL CONSIDERATIONS}

In a scenario of constant debate among Brazilian exporters and importers regarding the variables that influence freight rates, this study aimed not only to identify the variables involved on this matter, but also to characterize the relationships between these variables and freight rates in Brazilian trade to the USA, Europe and China. The final goal was also to help build a future tool that can predict oscillations or confirm the conservation of freight rates for the following period of shipments in Brazil.

A literature review of international databases of papers published in the past 20 years was conducted in this study (Exhibition 1 ) to identify the variables 
that, at least in theory, affect ocean freight rates. That research indicated 12 variables that influence the ocean freight rates. These variables were discussed in qualitative interviews with a panel of experts. It was found that some of these variables do not explain directly the oscillations in freight rates in Brazilian trade with the USA, Europe and China. That was the case of the variables distance sailed by the vessel and possibility of return cargoes. These aspects could be explained by the nature of the Brazilian international trade that is based on commodities like iron ore, soy, coffee, and sugar in exports (MDIC, 2017) and don't need containers for transportation. On the other hand, there are more cargoes that need containers for Brazilian imports. The distance sailed was studied and could affect more freight for commodities as wheat (Binkley \& Harrer, 1981).

Perhaps the same explanation could provide the reason of the variable economic situation of countries, which was cited by the specialists as one of the factors that less influence Brazilian ocean freight rates. It means that international commodities, the common goods exported by Brazil (MDIC, 2017), actually don't need containers. So, theoretically, one could argue that, given the lowest score, the variables distance sailed by the vessel, possibility of return cargoes and the economic situation of countries are suppressed or adjusted by the supply and demand of maritime transportation, as well as by the value of the goods transported.

Based on the experts' opinion, it was possible to observe that all relations presented in Exhibition 5 are capable of producing effect on Brazilian freight rates. However, although the variables discovered to influence the ocean freight rates charged in China trade route with Brazil are the same as those that affect rates in the USA and Europe trade with Brazil, a relationship observed can act in different manners in those two trades. For instance, during the two rounds of interviews, the specialists constantly underlined the stability between demand and supply as the main aspect to affect freight rates. When the demand for ocean transportation stabilizes within acceptable levels, considering the containers capacity made available by shipowners, the freight rates will eventually remain constant.

Nevertheless, in times when the demand for international transportation services increases, other different issues must be considered to influence freight rates, according to the specialists. These new set of variables can be the free slots available in vessels and new ships with higher capacity offered in the trade route. It could provoke lower freight rates charged in the market, and, therefore, and stimulate the demand for these services.

The results of the present study pointed to the need for further investigations using a quantitative approach to prove the statistical value of these variables in terms of ocean freight rates using correlation and regression tests, for instance. In addition, some Brazilian specific conditions such as exchange rate, based on the time series of freight rates, could help build a systemic modeling considering all variables associated with ocean freight rates. This would enable the prediction of oscillations in rates based mainly on the fluctuations in the variables listed.

In this same sense, this paper did not discuss the effect of the type of maritime freight service that can be provided by freight forwarders (OFFs) or by container shipping lines (CSLs) directly. Ho et al. (2017) found some differences in pricing and conditions for using one of those type o firms. Studies that could isolate the influence of the type of service offered in the formation of Brazilian maritime freight would be fruitful.

\section{REFERENCES}

Alphaliner Top 100. (2016). Retrieved from https://alphaliner. axsmarine.com/PublicTop100/

Anderson, J., \& van Wincoop, E. (2004). Trade costs. Journal of Economic Literature, 42(3), 691-751.

Armstrong \& Associates, Inc. (2015). 3P logistics. Retrieved from http://www.3plogistics.com/Top_25_Global_FF.htm

Aykol, B., Palihawadana, D., \& Leonidou, L. C. (2013). Research on the import activities of firms 1960-2010. Management International Review, 53(2), 215-250.

Ballou, R. H. (2004). Business logistics/supply chain management: Planning, Organizing and Controlling the Supply Chain. $5^{a}$ ed. Upper Saddle River, N. J. Pearson Prentice Hall.

Banomyong, R. (2005). The impact of port and trade security initiatives on maritime supply-chain management. Maritime Policy \& Management, 32(1), 3-46.

Bardin, L. (1977). Análise de conteúdo. Lisboa: Edições 70.

Binkley, J. K., \& Harrer, B. (1981). Major determinants of ocean freight rates for grains: an econometric analysis. American Journal of Agricultural Economics, 63(1), 47-57.

Bowersox, D. J., Cooper, M. B., Closs, D. J., \& Bowersox, J. C. (2014). Gestão logística da cadeia de suprimentos. São Paulo, SP: Bookman. 
Budescu, D. V., \& Rantilla, A. K. (2000). Confidence in aggregation of expert opinions. Acta Psychologica, 104, 371-398.

Bygballe, L. E., Bø, E., \& Grønland, S. E. (2012). Managing international supply: The balance between total costs and customer service. Industrial Marketing Management, 41(3), 394-401.

Creswell, J. W. (1998). Qualitative inquiry and research design: Choosing among five traditions. London, UK: Sage Publications.

Daividsson, P., Henesey, L., Ramstedt, L., Törnquist, J., \& Wernstedt, F. (2005). An analysis of agent-based approaches to transport logistics. Transportation Research Part C, 13, 255-271.

Finke, S., \& Kotzab, H. (2017). An inland-depots-for-emptycontainers-model for the hinterland. Maritime Business Review, 2(2), 126-141.

Fleury, P. F., Wanke, P., \& Figueiredo, K. F. (2012). Logística empresarial: A perspectiva brasileira. São Paulo, SP: Atlas.

Florentino, M. S. (2010). Gestão de custo no transporte marítimo de cargas no Brasil. Dissertação. MSc dissertation, Universidade do Estado do Rio de Janeiro, Faculdade de Administração e Finanças, Rio de Janeiro, Brazil.

Fung, M. K., Cheng, L. K., \& Qiu, L. D. (2003). The impact of terminal handling charges on overall shipping charges: an empirical study. Transportation Research Part A, 37(8) 703-716.

Grama, I. G. (2014). The importance of reducing freight rates and maritime transport costs. Economics, Management \& Financial Markets, 9(1), 292-302.

Hesse, M. \& Rodrigue, J.-P. (2004). The transport geography of logistics and freight distribution. Journal of Transport $\mathrm{Ge}$ ography, 12(3), 171-184.

Ho, T.C, Chiu, R.H., Chung, C.C., \& Lee, H.S. (2017). Key influence factors for ocean freight forwarders selecting container shipping lines using the revised DEMATEL approach. Journal of Marine Science and Technology, 25(3), 299-310.

Hummels, D. (2001). Toward a geography of trade costs. Purdue University: West Lafayette.

Hummels, D., Lugovskyy, V., \& Skiba, A. (2008). The trade reducing effects of market power in international shipping. Journal of Development Economics, 89(1), 84-97.

Jacks, D. S., \& Pendakur, K. (2010). Global trade and the maritime transport revolution. Review of Economics \& Statistics, 92(4), 745-755.

Mongelluzzo, B. (Aug 19, 2013) World's biggest container ports often also most efficient. Retrieved from https://www.joc. com/port-news/terminal-operators/worlds-biggest-container-ports-often-also-most-efficient_20130819.html

Kolbe, R. H., \& Burnett, M. S. (1991). Content-analysis research: An examination of applications with directives for improving research reliability and objectivity. Journal of Consumer Research, 18(2), 243-250.
Leach, P. T. (2014). South America: West's growth contrasts with protectionism in east. Journal of Commerce. Retrieved from http://www.joc.com/international-trade-news/trade-data/south-america-trade-data/south-america-west

Lee, T. C., \& Lee, P. T.W. (2012). South-South trade liberalization and shipping geography: a case study on India, Brazil and South Africa. International Journal of Shipping and Transportation Logistics, 4(4), 323-338.

Malchow, M. B., \& Kanafani, A. (2004). A disaggregate analysis of port selection. Institute of Transportation Studies, 40(4), 317-337.

Maloni, M., Paul, J. \& Gligor, D. (2013). Slow steaming impacts on ocean carriers and shippers. Maritime Economic \& Logistics, 15(2), 151-171.

Ministério do Desenvolvimento, Indústria e Comércio. (2017). Ministério do Desenvolvimento, Indústria e Comércio [online] Retrieved from http://www.mdic.gov.br

Murray, J. Y. (1996). A currency exchange rate-driven vs. strategy-driven analysis of global sourcing. Multinational Business Review, 4(1), 40-51.

Monroe, R. W., Teets, J. M., \& Martin, P. R. (2014). Supply chain risk management: an analysis of sources of risk and mitigation strategies. International Journal of Applied Management Science, 6(1), 4-21.

Notteboom, T., \& Cariou, P. (2013). Slow steaming in container liner shippings: is there any impact on fuel surcharge practices? The International Journal of Logistics Management, 24(1), 73-86.

Notteboom, T., \& Rodrigue, J. P. (2008). Containerisation, box logistics and global supply chains: The integration of ports and liner shipping networks. Maritime Economics \& Logistics, 10, 152-174.

Ortúzar, J. D., \& Willumsen, L. G. (1994). Modelling transport. 2 ed. West Sussex, UK: John Wiley.

Sahin, B., Yilmaz, H., Ust, Y., Guneri, A. F., \& Gulsun, B. (2007). An approach for analyzing transportation costs and a case study. European Journal of Operational Research, 193(1), $1-11$.

Slack, B., \& Gouvernal, E. (2011). Container freight rates and the role of surcharges. Journal of Transport Geography, 19(6), 1482-1489.

Steenken, D., Voß, S., \& Stahlbock, R. (2004). Container terminal operation and operations research - a classification and literature review. OR Spectrum, 26(1), 3-49.

Stopford, M. (2009). Maritime economics. 3 ed. London, UK: Routledge.

Tang, O., \& Sun, P. (2018). Anti-competition of ocean shipping alliances: A legal perspective. Maritime Business Review, 3(1), 4-19.

Trent, R. J., \& Monczka, R. M. (2003). Understanding integrated global sourcing. International Journal of Physical Distribution \& Logistics Management, 33(7), 607-629. 
Tseng, Y. Y., Yue, W. L., \& Taylor, M. A. P. (2005). The role of transportation in logistics chain. Eastern Asia Society for Transportation Studies, 5, 1657-1672.

United Nation Conference on Tariff and Trade. (2016) Review of Maritime Transport 2016. New York, NY: United Nations Publication.
Yaniv, I. (2004). The benefit of additional opinions. Current Directions in Psychological Science, 13(2), 76-79.

Zeng, A. C., \& Rossetti, C. (2003). Developing a framework for evaluating de logistics costs in global sourcing processes: an implementation and insights. International Journal of Physical, 33(9), 785-803. 